\title{
Moderation effect of client special treatment benefits on the relationship between logistics integra- tion and logistics performance in the logistics services providers' context
}

\author{
Najla Ayesh $^{a^{*}}$, Nik Hasnaa Bte Nik Mahmood ${ }^{b}$, Mas Bambang Baroto ${ }^{c}$ and Samah M.A. Mubarak
}

\author{
${ }^{a}$ Azman Hashim International Business School, Universiti Teknologi Malaysia, Kuala Lumpur, Malaysia \\ ${ }^{b}$ RAZAK Faculty of Technology \& Informatics, Universiti Teknologi Malaysia, Kuala Lumpur, Malaysia \\ ${ }^{c}$ Rhaz Techno Pro, Malaysia \\ ${ }^{d}$ Graduate School of Management, International Islamic University, Malaysia \\ C H R O N I C L E

\section{A B S T R A C T}

Article history:

Received: December 12, 2020

Received in revised format:

December 292020

Accepted: February 20, 2021

Available online:

February 20,2021

Keywords:

Relational view

LSP-Client Logistics integration

Relationship marketing

Special treatment benefits

Logistics performance

Logistics services providers
In the face of global competition and the coronavirus disease-19 (COVID-19) pandemic, the logistics service providers (LSPs) are facing severe challenges to attain their logistics performance indicators. To continue in such a market place, LSPs need to maintain a dedicated integration relationship with their clients by enhancing client special treatment benefits. The aim of this study is to apply the relational view (RV) theory and the relationship marketing (RM) perspective to examine the moderation effect of special treatment benefits on the link between logistics integration and LSPs' logistics performance (i.e., cost leadership and customer services innovation). Data was collected from 214 Malaysian LSPs, and analysed using partial least squares-structural equation modelling (PLS-SEM). Although the results show that logistics integration has a strong impact on both performances, further analysis shows that a high level of logistics integration has an association with high levels of special treatment benefits (moderating effect), in turn, maintaining performance at a high level. The exploring of the moderation effect of special treatment benefits contributes to the RV theory by incorporating the RM to reflect the moderation effect. Additionally, the study contributes empirically to the field of strategy and RM within the LSPs' industry. Finally, the findings enable LSPs to better allocate resources to ensure more effective value-based strategies that emphasise on client special treatment benefits to develop financial confidence and maintain longterm dedicated relationships, so as to achieve the target outcomes.

\section{Introduction}

Logistics, and the broader concept of supply chain management, alludes to the business function of providing goods in the required amount and cost at the required time and spot (Karia, 2011; Speranza, 2018). Logistics services comprise a series of activities beyond transportation, including express delivery, warehousing, terminal operations, brokerage, and management of the related information (Erna, Surachman, Sunaryo, \& Djajuli, 2019). The global logistics industry is developing rapidly; its global turnover exceeds USD 4.3 trillion (Erna et al., 2019; Ju, Wang, Cheng, \& Jia, 2019). For Southeast Asia, Malaysia's global ranking in light of the Logistics Performance Index by the World Bank Report 2018, has changed marginally in the last few years, from 25th in 2014, 32nd in 2016 and 41st in 2018, with a decrease in all the performance indicators, starting from the efficiency of the clearance process to the timeliness of shipments in reaching the destination within the expected delivery time (Arvis et al., 2018). During the global outbreak of the coronavirus disease-19 (COVID-19), the world's logistics industry, specifically Malaysia's, is facing issues due to its vulnerable conditions, compared to top performing countries, both

* Corresponding author.

E-mail address: amanajla2@graduate.utm.my (N. Ayesh) 
internationally (for example, Germany) or regionally (for example, Japan). Previously, global competitiveness, cost reduction and service improvement, etc., were the important factors that stimulated firms to use the logistics service providers (LSPs) as specialist firms to perform part or whole of the logistics functions on their behalf (Gadde \& Hulthén, 2009; Mello, Stank, \& Esper, 2008). However, during the pandemic, the business-to-consumer logistics market has expanded widely and has assumed an extremely critical role (Hobbs, 2020; Sharma, 2020). According to the World Health Organization (2020), the big challenge faced by the global supply chain industry is to maintain a smooth supply of goods, whilst adhering to pandemic control measures. In response, LSPs need to optimize their operations, and more importantly, improve their resources through proactive and innovative supply chain practices in logistics integration, so that their position is better than their competitors (Arvis et al., 2018; Karia, Wong, Asaari, \& Lai, 2015; Kumar, 2017; Liu \& Lee, 2018). Studies have widely used theories, as the resource-based view (RBV) theory (Barney, 1991) and the RV theory (Dyer \& Singh, 1998), and established that supply chain integration within the logistics sector, as an inter-firm collaboration, can be a wellspring of LSPs' permanent competitive advantage. (Liu \& Lee, 2018; Wiengarten, Li, Singh, \& Fynes, 2019; Yuen \& Thai, 2016). Therefore, as the world acclimates to the new normal as required by the pandemic, the logistics integration model is insistently required to leverage logistics resources to have an efficient movement of goods, thereby contributing to competitive advantage and sustainability (Karia, 2019; Wang, Persson, \& Huemer, 2016), as well as for eventual economic recovery (Erna et al., 2019; Sharma, 2020). However, there is considerable proof in the literature that a higher degree of supply chain integration does not constantly improve performance of the firm (Wiengarten et al., 2019); in fact, it is often seen as being unsuccessful and costly (Pateman, Cahoon, \& Chen, 2016; Tsanos, 2016). Consequently, it has been suggested that previous studies may have created models that were oversimplified (linked integration directly to performance), neglecting the role of moderating or contingency factors (Ataseven \& Nair, 2017; Wiengarten et al., 2019).

Marketing, logistics and strategy researchers have emphasised on a balance between the value creation processes and value appropriation (mutual process of dual-value exchange) as the foundation for successful collaboration initiatives (Ellegaard, Medlin, \& Geersbro, 2014; Kumar \& Reinartz, 2016; Zhang \& Du, 2019). The client's special treatment benefits (i.e., monetary benefits) are built on the assumption of the RM perspective, i.e., for a solid relationship to exist, the service provider, and more importantly, the client, must benefit (Gremler, Van, Brüggen, \& Gwinner, 2019; Gwinner, Gremler, \& Bitner, 1998). Client value appropriation, represented by customer special treatment benefits, is essential for building strong mutual relationships and for shaping competitive advantage of the firm (Gremler et al., 2019; Gwinner et al., 1998; Hennig-Thurau, Gwinner, \& Gremler, 2002). It can be inferred that LSPs can improve their performance through more effective logistics integration practices and by creating a win-win situation via positive monetary benefits to clients who show their continued interest to maintain their relationship with them. To our best knowledge, only a limited number of studies have treated special treatment benefits as a moderator variable (e.g., Lien, Wu, \& Hsu, 2018; Soni, 2019), and it has been either linked to RM dimensions or considered through customer outcomes (e.g., continuity, loyalty and word-of-mouth [WOM]) as the study constructs. Based on this review, this paper examines the moderating effect of special treatment benefits on the link between logistics integration and logistics performance. The insights from this study would clarify the role of relationship benefits, especially client appropriation, in preserving the links between inter-firm collaboration and firm performance.

\section{Literature Review}

\subsection{Logistics Performance}

Logistics performance refers to the ability of the firm to achieve cost advantage and/or services advantage, that is not emulated by its competitors (Karia, 2011; Karia, Asaari, \& Wong, 2014). It is also defined as the level of differentiation and efficiency that is linked to the achievement of logistics activities (Mentzer, Min, \& Bobbitt, 2004). Logistics providers should therefore endeavour to minimise the amount of resources utilised as opposed to the results derived (efficiency), achieve the predefined objectives (effectiveness), and attain a superior standing in the marketplace (differentiation) (Tuan, 2017). According to the theory of competitive advantage by Porter (1985), firms can achieve outstanding performance by implementing cost leadership and/or differentiation strategies better than their competitors (Musia, 2013; Porter, 1980). Currently, researchers are becoming increasingly more interested in the non-financial elements to measure performance due to the nature of the industry outputs (intangible and difficult to quantify). Examples of the non-financial elements applied are service performance in terms of quality, flexibility and delivery (e.g., Brah \& Lim, 2006; Kirono, Armanu, Hadiwidjojo, \& Solimun, 2019; Wiengarten et al., 2019); service variety or innovative services (Erna et al., 2019; Hofer, Knemeyer, \& Murphy, 2012; Ju et al., 2019); and cost (Kirono et al., 2019; Lewis, 2006; Wiengarten et al., 2019). LSPs' performance measurement should be multidimensional to reflect the operations and to avoid misleading conclusions (Karia et al., 2014; Ray, Barney, \& Muhanna, 2004). Based on Porter's (1985) theory of competitive advantage, Karia (2011) developed and conceptualised LSPs' performance into two competitive performance metrics: competitive costs or cost leadership; and competitive services or customer services innovation.

\subsubsection{Cost Leadership}

Cost leadership refers to operational cost reduction; it means the LSPs' ability to reduce transportation costs, inventory costs and warehousing costs and achieve cost advantages that are reflected in lower service costs (Karia et al., 2015). In other words, cost leadership may be defined as cost reduction or an operational cost saving on transportation and goods carried (Kirono et al., 2019). Other conceptual cost advantages resulting from effectiveness and efficiency in operation, include low-cost transport/ distribution operations (e.g., improvement in utilisation of resources, reduced inaccurate deliveries); labour (i.e., 
increased employees' productivity and reduced number of administrative employees); and reduced warehouse/inventory and equipment (i.e., processing cost, improved utilisation and cycle times reduction) (Hazen \& Byrd, 2012; Karia, 2018b, 2019).

\subsubsection{Customer Services Innovation}

Customer services innovation is the LSPs' ability to achieve advantage in service differentiation in terms of flexibility, delivery reliability, delivery quality and service variety (Karia et al., 2015). Erna et al. (2019) considered radical and incremental service and open-innovation as measures of LSPs' service innovation performance. Lyu, Chen, and Huo (2019a) conceptualised and measured service performance in terms of on-time delivery, order-fill rate, turnover ratio of inventory, and operational flexibility. Wiengarten et al. (2019) and Liu, Huo, Liu, and Zhao (2015) regarded quality, delivery, and flexibility as important measures for service performance. Considering cost leadership and customer services innovation to measure LSPs' performance is more suitable to reflect the LSPs' competitive position compared to other service providers. In particular, the multidimensional measures are relevant in the context of logistics integration, where a holistic conceptualisation of performance measures would help in connecting logistics integration to performance (Ataseven \& Nair, 2017; Feizabadi, Gligor, \& Motlagh, 2019).

\subsection{Logistics Integration}

In its simplest form, supply chain integration can be conceptualised as a unidimensional construct that contains various coordinative and collaborative activities practiced by firms (e.g., Ju et al., 2019; Prajogo \& Olhager, 2012). At a more complex level, supply chain integration is characterised as a multidimensional construct. The most frequent conceptualised method is based on its direction, whether it is external or internal integration (e.g., Flynn, Huo, \& Zhao, 2010; Wiengarten et al., 2019). In this study, external logistics integration with the LSPs' key clients, be it the supplier or the customer, is the construct of interest. Logistics integration can be considered as partnerships or practices that align the firm's internal operations with its external processes (Cao, Vonderembse, Zhang, \& Ragu-Nathan, 2010). Ideally, these practices have to eliminate any barriers that prevent the flow of supply chain's materials, funds, and related information (Frohlich \& Westbrook, 2001; Wiengarten et al., 2019). Prior studies on logistics have generally regards sharing of timely and sensitive data, working together, joint planning, resolving problems and exploring market opportunities together, as important elements to create a strategic partnership between LSPs and their clients (Hartmann \& De Grahl, 2011; Karia, 2019; Liu \& Lee, 2018). For example, Yuen and Thai (2016) defined logistics integration as the level to which a LSP can partner with its main supplier and/or customer to construction their inter-firm activities, practices, strategies and behaviour into a collaborative and manageable process to fulfil clients' needs. As logistics integration is still an under-researched concept from the perspective of LSPs, its regarded in this study as the level to which a partner can strategically collaborate with its partners in supply chain and manage tasks and logistics activities collaboratively across the supply chain (Lai, Chu, Wang, \& Fan, 2013).

The RV theory assumes that a firm cannot realise competitive advantage when it depends on its resources and capabilities in isolation (Dyer \& Singh, 1998; Lavie, 2006). This is because collaboration creates value via access to previously inaccessible resources and broadening the application of resources to attain unique configuration so that its value is maximised comparative to other potential combinations (Das \& Teng, 2000; Ireland, Hitt, \& Vaidyanath, 2002). Similarly, logistics studies have applied the RBV and/or the RV theory to reflect the logistics integration capability and to further provide evidence that working closely together, coordinating and sharing resources, can expand the clients' and LSPs' resources (Kirono et al., 2019; Sinkovics \& Roath, 2004), besides providing effective flow and access to partners' knowledge (Richey, Adams, \& Dalela, 2012; Srivastava, Srinivasan, \& Iyer, 2015). These then lead to important capabilities, such as flexibility and responsiveness (Hartmann \& De Grahl, 2011; Liu \& Lee, 2018; Yang, Xie, Liu, \& Duan, 2018); and cost saving, customer satisfaction, and services innovation (Karia, 2019; Wagner \& Sutter, 2012). Empirical evidence exists that the integrative mechanisms with extensive information sharing can be leveraged by LSPs to create logistics capabilities, such as knowledge-based resources, which can lead to substantial improvement in delivery, service quality and performance flexibility (Kirono et al., 2019; Liu et al., 2015). Extensive collaboration and working closely together facilitate the rapid flow of operational and strategic information among LSPs and clients, which can reduce conflict and misunderstanding (Kirono et al., 2019); enhance trust (Ju et al., 2019); and enable better control and execution of resources (Lai, Zhao, \& Wang, 2006; Yuen \& Thai, 2017; Zhang \& Cao, 2018). Hence, logistical processes can be performed efficiently and effectively (Ju et al., 2019; Jimenez-Jimenez, MartínezCosta, \& Rodriguez, 2019), which in turn, can enhance the overall performance of LSPs, in terms of cost, accuracy, delivery and satisfaction (Irfan \& Wang, 2019; Sanders \& Premus, 2005). Hence, this study hypotheses that:

$\mathbf{H}_{1}$ : Logistics integration is significantly associated with cost leadership.

$\mathbf{H}_{2}$ : Logistics integration is significantly associated with customer services innovation.

\subsection{Special Treatment Benefits}

Special treatment benefits relate to economic benefits, such as discounts/price breaks and extra services or fast delivery (Bendapudi \& Berry, 1997; Gwinner et al., 1998). It refers to relationship benefits that customers receive beyond the core service performance (Gwinner et al., 1998). This study focuses specifically on special treatment benefits for the following reason: according to the recent review of literature by Gremler et al. (2019), several relational benefits concepts that have been identified are without a well-built structure. Additionally, when compared to social benefits and confidence benefits, the role of special treatment benefits is weak or debated. This may be due to the majority of the studies having measured special 
treatment benefits either as a predictor or as a mediator, but not as a moderating variable that influences loyalty components (Soni, 2019). Many relational-based studies have built on the RM perspective of Gwinner et al. (1998) to understand those benefits (e.g., Alhathal, Sharma, \& Kingshott, 2019; Kinard \& Capella, 2006; Soni, 2019). Special treatment benefits were extended further to the logistical setting by Palaima and Auruškeviciene (2007); Li (2011); and Li, Ford, Zhai, and Xu (2012). Their results confirm that logistics services comprise those benefits. Li et al. (2012) adjusted them to be applicable to the LSPs' environment. They defined special treatment benefits as those rewards and benefits customers receive from their relationship with LSPs, which focus mainly on competitive prices, shipping rates, and reduced delivery lead-time. Based on the same premise, Balci, Caliskan, and Yuen (2019) found financial bonding as a RM strategy, particularly pertinent to the intangible nature of the LSPs' services. They empirically showed that financial bonding reinforces customers' satisfaction and their loyalty to Turkish container lines.

Strategy (e.g., Andersén, 2011; Khanna, Gulati, \& Nohria, 1998; Lavie, 2006) and marketing (e.g., Anderson \& Marks, 1995; Gronroos, 1990; Ulaga \& Eggert, 2006b) theorists have underscored that value creation and value appropriation are the foundations for the existence of any business relationship. Put differently, participation in integration can either benefit or damage the quest of a firm for competitive advantage, when the firm overlooks the parallel distribution of mutual relational benefits (Andersén, 2011; Khanna et al., 1998; Lavie, 2006, 2007). Based on that, clients that doubt their partner's (LSP's) opportunistic behaviour, tend to restrict the scope of integration and transfer of knowledge, which are crucial for mutual benefits and competitive advantage to be sustained (Dyer \& Singh, 1998; Lavie, 2006; Parkhe, 1993). Based on that, Zhang and Du (2019) posited that service providers can leverage on their inter-firm cooperation capability to improve value appropriation; however, they also proved that customer value has a positively direct effect on the provider's appropriate value, i.e., finance, profit and new service development. They argued that both issues, i.e., creating customer value and appropriating value in profits, combine and interact, to contribute to the provider's competitive advantage. This could perhaps explain why marketing literature is of the view that the fulfilment of client's special treatment benefits is a human need in any relationship bond and is regarded as the basis for the continuity and stability of the relationship in the long-run (e.g., Berry, 1995; Lee, Kim, Kim, Lee, \& Lim, 2015; Lien et al., 2018; Moliner-Velazquez, Fuentes-Blasco, \& Gil-Saura, 2014; Soni, 2019; Yrjölä, Rintamäki, Saarijärvi, Joensuu, \& Kulkarni, 2019). Those benefits are ordinarily provided to clients who show some degree of patronage; experiencing those benefits from such level of patronage then reinforces their loyalty (Lee et al., 2015; Yrjölä et al., 2019). Loyal clients are bound to purchase extra services and make positive WOM recommendations to others (Zeithaml, Berry, \& Parasuraman, 1996), which ultimately impact business performance (Watson, Beck, Henderson, \& Palmatier, 2015).

The LSP business is not the exception; the degree to which LSPs succeed in providing superior customer value, represented by special treatment benefits, leads to customer satisfaction, loyalty, engagement and profitability, and eventually, competitive advantage. For example, FedEx-Taiwan gives a strong impression of "over- night delivery" by adopting excellent strategic methods in its transport services, thereby becoming outstanding in an extremely competitive environment, in terms of price and quality (Ding et al., 2016). Today's customers are more price-sensitive, and this may be why Palaima and Auruškeviciene (2007) found that achieving service quality is not enough in the parcel delivery sector, because customers' special treatment benefits are essential for showing commitment to the relationship with them. Balci et al. (2019) found financial benefits strategies, like deferred payments or discounts, price incentives, volume discounts, and freight rates of container carriers, have the strongest overall effect on loyalty in addition to its direct effect on customer satisfaction. It has been proven that relational benefits mitigate the negative effect of opportunistic behaviour, and the dysfunctional conflict on willingness to share knowledge between supply chain partners (Cheng, Chen, \& Chen, 2013). This is because providing clients with economic benefits, such as competitive prices, shipping rates, and favourable payment terms, and offering attractive discounts, are significant drivers that influence commitment, trust, clients-LSPs' long-term strategic relationship and relational outcomes, in terms of volume of sales, position in the marketplace and smooth process within supply chain (Li et al., 2012), through their effects on clients' satisfaction and loyalty (Li, 2011). Hence, this study hypotheses that:

H3: Special treatment benefits moderate the relationship between logistics integration and cost leadership.

H4: Special treatment benefits moderate the relationship between logistics integration and customer services innovation.

Founded on the above theoretical and empirical arguments, this study examines the four hypotheses developed as shown in Fig. 1.

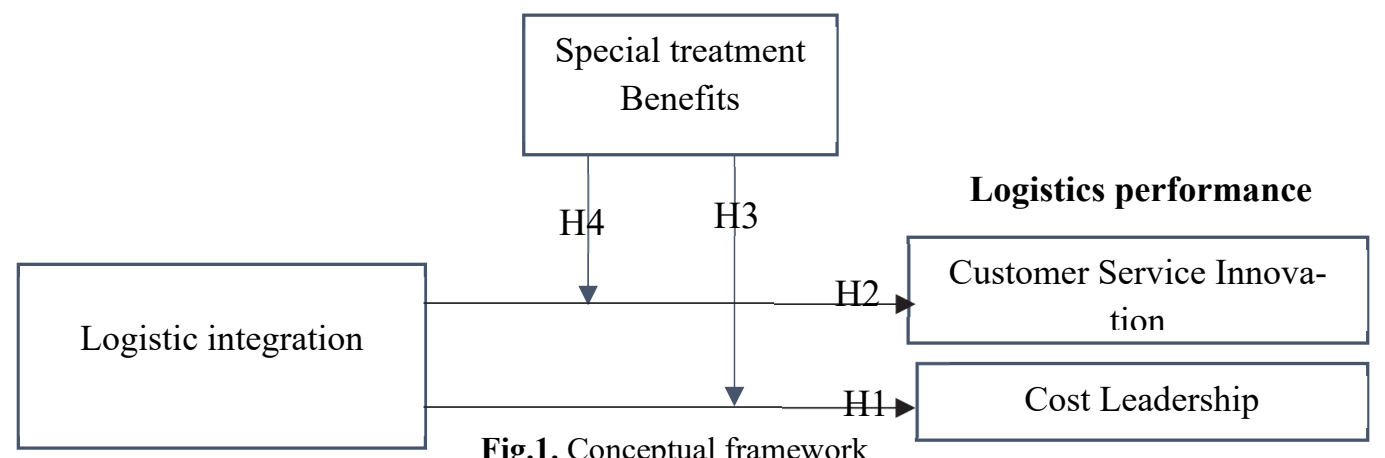

Fig.1. Conceptual framework 


\section{Research Methods}

\subsection{Collection the Data and Measurement Items}

This study examines the moderation effect of client's special treatment benefits on the link between logistics integration and logistics performance i.e., cost leadership and customer services innovation, by applying a quantitative research design. Data was collected using a self-administered mail survey and based on a single informant from logistics companies located in the Klang Valley, Malaysia. This study utilised multi-stage sampling methods, specifically, the study implemented a sequential sampling design (Collins, Onwuegbuzie, \& Jiao, 2006). At the first stage, a simple random sampling was applied, using Malaysia Logistics Directory 2016/2017 as a sample frame. Out of 140 filled questionnaires, 96 were identified as usable. At the second stage, convenience sampling was applied by targeted logistics companies in logistics conferences and exhibitions. Out of 130 filled questionnaires, 118 were identified as usable. Thus, out of a total 270 filled questionnaires, 214 usable questionnaires were utilized in the analysis (response rate of 79.2\%). The questionnaire consisted of five sections: the first three sections included the measurement of the constructs being studied, and the other two sections included the sociodemographic features and demographic profile. Logistics performance was measured by metrics adopted from Karia et al. (2014). Cost leadership was measured by three items, while customer services innovation was measured by six items. Logistics integration was measured by nine items adopted from Lai et al. (2013). The moderating variable was adopted from Li (2011) and measured by four items (Appendix). The items for all the variables studied were measured using a five-point Likert scale, with 1 "strongly disagree" and 5 "strongly agree".

\subsection{Statistical Analysis}

Structural equation modelling (SEM) was applied in this study to analyse the data collected from the target sample. SEM not only allows assessing the hypothesised relationships between constructs in the structural model, but also the link between construct and their respective measurement items (Carvalho \& Chima, 2014). SEM takes into account a sequence of methods that allows multiple relationships between one or more than one latent independent variable and one or more than one latent dependent variable, both measured by several indicators. In particular, this study applied variance-based SEM, known as Partial Least Squares Structural Equation Modelling (PLS- SEM) using Smart-PLS version 3 software (Ringle, Wende, \& Becker, 2015). PLS-SEM is appropriate when the objective is for prediction and theory development (Hair, Risher, Sarstedt, \& Ringle, 2019; Sarstedt, Ringle, \& Hair, 2017). In this study, the focus is on determining the best prediction of relationships among variables as well as on maximising the covariance among latent variables toward increasing the interpretation of the study model. Additionally, PLS-SEM is only meant for an exploratory study and theory development due to its statistical power in cases where the target is to uncover the strong effect and the theory is less developed (Chin, 2010; Hair, Hult, Ringle, $\&$ Sarstedt, 2014). This study is regarded as exploratory in nature, since it attempts to explore the moderating effect of special treatment benefits on the link between logistics integration and logistics performance, in terms of cost leadership and customer services innovation.

\section{Results}

\subsection{Sociodemographic Features and Demographic Profile}

The results (Table 1) indicate that most of the respondents have a bachelor's degree (64.5\%), followed by a Master's degree and higher (18.7\%). The highest percentage for positions is for manager (51.4\%), followed by managing director (27.6\%) and supervisor (19.2\%). Around $69.2 \%$ and $69.6 \%$ of respondents have high levels of knowledge and skills, followed by moderate levels $(30.9 \%$ and $30.4 \%)$, respectively. The results also indicate that the average work experience with current employer is $\mathrm{M}=8.173$ years with standard deviation of $\mathrm{SD}=3.4102$, while the average for total experience is $\mathrm{M}=12.529$ with standard deviation of $\mathrm{SD}=3.5607$, which means that around two-thirds of the respondents are 3.5607 less experienced and 3.5607 with higher experience than the mean of $M=12.52$. Therefore, it can be concluded that the collected information is reliable, as respondents had answered the questions within their domain of responsibility. Additionally, Table 1 shows that the majority of companies (66\%) have more than 75 employees (141 companies), followed by companies with 30 to 75 employees accounting for $13.5 \%$ of the sample (29 companies). The highest frequency for ownership is observed for local companies $(61.2 \%)$, followed by joint-ventures $(22 \%)$. Finally, the years the logistics companies have been working has a mean of $\mathrm{M}=$ 21.51 years (ranges between one to 32 years), while the mean for the length of contract with its respective key client is $\mathrm{M}=11.53$ with standard deviation of $\mathrm{SD}=6.125$, which means that around two-thirds of the companies' contract length is 6.125 shorter and 6.125 longer than the mean of $\mathrm{M}=11.53$.

Fig .2 displays the distribution for the main businesses. Most of the companies are active in transportation and delivery (213), 198 are in warehousing, 99 are in the shipping business, and 98 in freight-forwarding. The lowest frequency is courier services at 15 companies. Hence, it can be concluded that the firms included in the sample carry out part or full logistics services. 
Table 1

Frequency and Descriptive Statistics of Sociodemographic Features and Companies' Profile

\begin{tabular}{|c|c|c|c|}
\hline Respondents & Level & Frequency & $\%$ \\
\hline \multirow[t]{3}{*}{ Edu level } & Diploma/Certificate & 36 & 16.8 \\
\hline & Degree & 138 & 64.5 \\
\hline & Master's and above & 40 & 18.7 \\
\hline \multirow[t]{4}{*}{ Position } & President & 4 & 1.9 \\
\hline & Managing Director & 59 & 27.6 \\
\hline & Manager & 110 & 51.4 \\
\hline & Supervisor & 41 & 19.2 \\
\hline \multirow{3}{*}{ Knowledge } & Low & 0 & 0 \\
\hline & Moderate & 66 & 30.8 \\
\hline & High & 148 & 69.2 \\
\hline \multirow[t]{4}{*}{ Skill } & Low & 0 & 0 \\
\hline & Moderate & 65 & 30.4 \\
\hline & High & 149 & 69.6 \\
\hline & (Min-Mix) & Mean & SD \\
\hline Current position experience & 2 -to- 19 & 8.173 & 3.4102 \\
\hline Total experience & 1.1 -to- 22 & 12.529 & 3.5607 \\
\hline Companies & Level & Frequency & $\%$ \\
\hline \multirow[t]{3}{*}{ Number of employees } & Less than 30 & 44 & 20.5 \\
\hline & 30 -to- 75 & 29 & 13.5 \\
\hline & More than 75 & 141 & 66.0 \\
\hline \multirow[t]{4}{*}{ Ownership } & Local company (Malaysian) & 131 & 61.2 \\
\hline & Joint venture & 47 & 22 \\
\hline & Foreign company & 36 & 16.8 \\
\hline & (Min-Mix) & Mean & SD \\
\hline No of working years & 1 -to- 32 & 21.51 & 8.839 \\
\hline Length of contract & 2 -to- 21 & 11.53 & 6.125 \\
\hline
\end{tabular}

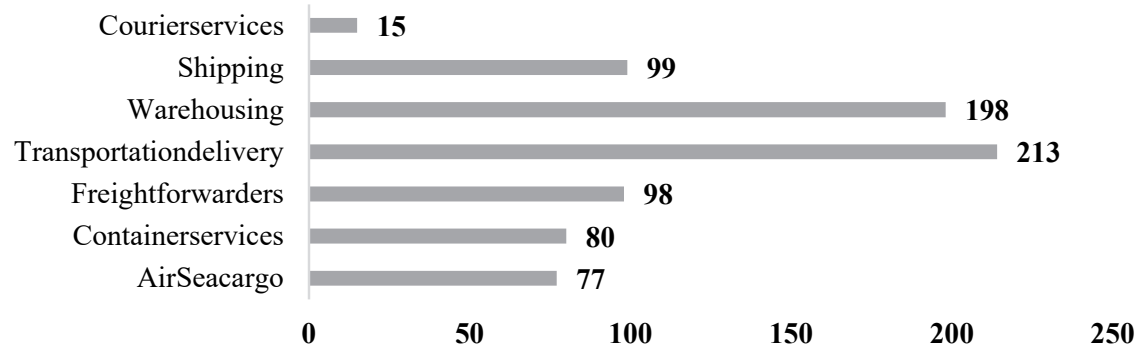

Fig. 2. Distribution for the Companies' Main Business

\subsection{Descriptive Statistics of the Variables}

Table 2 displays the descriptive statistics on the rating related to the four measurement scales used based on the five-point Likert scale. Based on the aggregate mean for all the items for each scale, the respondents indicated their level of agreement on cost $(M=2.97, S D=0.94)$, customer services innovation $(M=3.05, S D=1.01)$, logistics integration $(M=3.27, S D=0.85)$, and special treatment benefits $(\mathrm{M}=3.38, \mathrm{SD}=1.00)$, at almost the median of scale (3). This indicates that the level of agreement on those variables is at a moderate level.

\subsection{Measurement Model Assessment}

Since all the measurement items were adopted from existing literature, the validity and reliability of the measures are verified. Table 2 shows the PLS-SEM results for construct validity and internal consistency reliability. In terms of construct validity, all the indicators exhibit outer loading above 0.70, which means that all indicators have an adequate level of reliability (Hair, Ringle, \& Sarstedt, 2011). The exception is the item related to logistics integration, " $L I$ _ ", which was deleted from the measurement model because of its low loading factor below than 0.5 , which confirms its low contribution to logistics integration (Hair et al., 2011); while the item related to customer services innovation, "CSI 9", was not excluded from the initial measurement model, because the average variance extracted (AVE) (0.639) and composite reliability (CR) (0.913) of the construct are still above the cut-off $(>0.50$ and $>0.70)$, respectively (Henseler, Ringle, \& Sinkovics, 2009). Further, the AVE values to assess convergent validity for all constructs range between 0.551 to 0.678 , which are over the acceptable level of 
0.5 (Fornell \& Larcker, 1981; Gefen, Straub, \& Boudreau, 2000; Hair, Sarstedt, Ringle, \& Gudergan, 2017). Hence, the results provide support for construct validity in this study. In terms of internal consistency reliability, Cronbach's alpha values range from 0.762 to 0.926 and CR values range from 0.863 to 0.944 , which are considered satisfactory (Hair, Ringle, \& Sarstedt, 2011; Hair et al., 2017). Hence, the constructs in this study exhibit adequate levels of internal consistency reliability. Tables 3 and 4 show the results of the Fornell-Larcker criterion and Hetrotrait-Monotrait (HTMT) Ratio of Correlation Criterion to assess discriminant validity. As observed in Table 3, the square root of AVE for each construct is greater than other values below the bold diagonal values (Fornell \& Larcker, 1981; Hair, Black, Babin, \& Anderson, 2010). The HTMT values in Table 4 for each pair of constructs is below than 0.85 (Henseler, Ringle, \& Sarstedt, 2015), indicating that all constructs in this study not correlated and completely distinct from each other (Henseler et al., 2015). Hence, the result provides support for construct discriminant validity.

Table 2

Descriptive Statistics and PLS-SEM Result of Construct Validity and Reliability

\begin{tabular}{|c|c|c|c|c|c|c|c|}
\hline \multirow{2}{*}{ Construct and Items } & \multicolumn{2}{|c|}{ Descriptive statistics } & \multicolumn{2}{|c|}{ Outer loading } & \multirow{2}{*}{ AVE } & \multirow{2}{*}{ Cronbach's Alpha } & \multirow{2}{*}{ CR } \\
\hline & Mean & SD & Initial model & Modified model & & & \\
\hline Cost leadership & & & & & 0.678 & 0.762 & 0.863 \\
\hline$C L . \_1$ & 2.69 & 1.30 & 0.882 & 0.882 & & & \\
\hline CL._5 & 2.99 & 1.25 & 0.783 & 0.783 & & & \\
\hline CL. 8 & 2.81 & 1.22 & 0.803 & 0.803 & & & \\
\hline Total & 2.97 & 0.94 & & & & & \\
\hline Customer service innovation & & & & & 0.639 & 0.883 & 0.913 \\
\hline CSI._2 & 2.99 & 1.38 & 0.822 & 0.822 & & & \\
\hline CSI._3 & 2.85 & 1.3 & 0.834 & 0.834 & & & \\
\hline CSI. 4 & 2.98 & 1.27 & 0.868 & 0.868 & & & \\
\hline CSI._6 & 3.04 & 1.20 & 0.817 & 0.817 & & & \\
\hline CSI. 7 & 3.00 & 1.26 & 0.829 & 0.829 & & & \\
\hline CSI._9 & 3.42 & 1.17 & 0.594 & 0.595 & & & \\
\hline Total & 3.05 & 1.01 & & & & & \\
\hline Logistics Integration & & & & & 0.659 & 0.926 & 0.939 \\
\hline LI._1 & 3.51 & 1.07 & 0.776 & 0.784 & & & \\
\hline LI._2 & 3.53 & 0.98 & 0.812 & 0.815 & & & \\
\hline L.I 3 & 3.45 & 1.06 & 0.833 & 0.838 & & & \\
\hline LI. 4 & 3.43 & 1.01 & 0.850 & 0.856 & & & \\
\hline LI._5 & 3.51 & 1.08 & 0.844 & 0.852 & & & \\
\hline LI._6 & 3.13 & 1.11 & 0.792 & 0.786 & & & \\
\hline LI. 7 & 2.87 & 1.18 & 0.442 & Deleted & & & \\
\hline LI._8 & 3.06 & 1.13 & 0.770 & 0.765 & & & \\
\hline LI. 9 & 2.92 & 1.28 & 0.794 & 0.796 & & & \\
\hline Total & 3.27 & 0.85 & & & & & \\
\hline Special treatment benefits & & & & & 0.551 & 0.788 & 0.831 \\
\hline STB._1 & 3.35 & 1.36 & 0.743 & 0.743 & & & \\
\hline STB._2 & 3.39 & 1.38 & 0.765 & 0.765 & & & \\
\hline STB. 3 & 3.57 & 1.32 & 0.753 & 0.753 & & & \\
\hline STB. 4 & 3.22 & 1.36 & 0.760 & 0.760 & & & \\
\hline Total & 3.38 & 1.00 & & & & & \\
\hline
\end{tabular}

Table 3

Correlation of Latent Variables and Discriminant Validity by Fornell-Larcker Criterion

\begin{tabular}{|c|c|c|c|c|}
\hline Construct & Cost leadership & Customer service innovation & Logistics integration & Special treatment benefits \\
\hline Cost leadership & 0.824 & & & \\
\hline Customer service innovation & 0.693 & 0.799 & & \\
\hline Logistics integration & 0.716 & 0.765 & 0.812 & \\
\hline Special treatment benefits & 0.171 & 0.277 & 0.123 & 0.743 \\
\hline
\end{tabular}

Table 4

Correlation of Latent Constructs and Discriminant Validity by HTM

\begin{tabular}{|c|c|c|c|c|}
\hline Construct & Cost leadership & Customer service innovation & Logistics integration & Special treatment benefits \\
\hline \multicolumn{5}{|l|}{ Cost leadership } \\
\hline Customer service innovation & 0.84 & & & \\
\hline Logistics integration & 0.849 & 0.841 & & \\
\hline Special treatment benefits & 0.163 & 0.276 & 0.126 & \\
\hline
\end{tabular}

\subsection{Structural Model Assessment}

The initial step in the structural model evaluation began by checking the collinearity issues between the constructs. As the result shows in Table 5, all the variance inflation factor (VIF) values are below the cut-off of five, showing that collinearity among the exogenous variables is not a problem (Hair et al., 2011; Myers, 1997). Subsequently, the assessment for the structural model's predictive accuracy started by evaluating the coefficient of determination $\left(\mathrm{R}^{2}\right)$. The $\mathrm{R}^{2}$ for cost leadership is 
moderate (Hair et al., 2011) at 0.535 , which indicates that $53.5 \%$ of cost leadership variance could be explained by constructs related to $\mathrm{CL}$. The $\mathrm{R}^{2}$ for customer services innovation is relatively high (Hair et al., 2011) at 0.632 , which means that $63.2 \%$ of changes can be explained by constructs related to CSI. Further, Table 5 presents the result of effect size $\left(f^{2}\right)$, which indicates that the highest $f^{2}$ for CL and CSI occurs for its relationship with logistics integration $\left(f^{2}=1.076, f^{2}=1.495\right)$, respectively, which are large $f^{2}$ (Cohen, 1988). Except for special treatment benefits on cost, all other $f^{2}$ in the structural model are above 0.02 (Cohen, 1988), and are not negligible. Finally, the blindfolding approach to assess cross-validated redundancy measures to find predictive relevance $\left(\mathrm{Q}^{2}\right)$ values was applied. The $\mathrm{Q}^{2}$ values for CL (0.359) and CSI (0.394) are larger than zero, indicating that the constructs have predictive relevance for CL and CSI in this study (Hair, Hult, Ringle, \& Sarstedt, 2016).

Table 5

Collinearity Assessment based on VIF using PLS-SEM

\begin{tabular}{lccc}
\hline \multirow{2}{*}{ Construct } & \multicolumn{2}{c}{ Effect Size f } & \multicolumn{2}{c}{ Collinearity VIF } & CL & CSI & 1.019 & 1.019 \\
\cline { 2 - 4 } & CL & 1.495 & 1.045 \\
Logistics Integration & 1.076 & 0.035 & 1.045 \\
Special treatment benefits & 0.028 & 0.067 & 1.059 \\
\hline
\end{tabular}

e CL: Cost leadership, CSI: Customer services innovation, LI: Logistics integration, SB: Special treatment benefits

\subsection{Path Results and Hypothesis Testing}

To explore whether the special treatment benefits significantly moderate the relationship between logistics integration and logistics performance i.e., cost leadership and customer services innovation, the interaction effect of special treatment benefits was added to the model using Smart-PLS based on the two stage-approach (Chin, Marcolin, \& Newsted, 2003). The PLSSEM path coefficient was carried out to assess the hypotheses of this study. Then, the bootstrapping procedure was employed to evaluate the statistical significance of these coefficients. Figure 3 shows the path model and bootstrapping results, standardised path coefficients $(\beta)$, and p-values for each path in the structural model. As observed from the results, all the coefficients (except for special benefits on CL) are above 0.10 , which is an indication of a meaningful positive impact on the structural model (Henseler et al., 2009). Table 6 shows the standardised path coefficients ( $\beta$ ), T-value and $p$-values for each hypothesis in each path. As observed from the results, logistics integration has a positive and significant impact on cost $\left(\beta=0.724^{* *}, p=0.001\right)$ and customer services innovation $\left(\beta=0.749^{* *}, p<0.001\right)$. Further, the moderating effect of special treatment benefits on the link between logistics integration and logistics performance is positive and statistically significant for $\operatorname{cost}\left(\beta=0.115^{*}, p=0.012\right)$ and customer services innovation $\left(\beta=114^{* *}, p=0.003\right)$, which means special treatment benefits positively moderates the link between logistics integration and logistics performance. The results reveal that an increase in the level of special treatment benefits will strengthen the relationship between logistics integration and logistics performance, in terms of cost and customer services innovation, which can be seen in the graph of slope analysis (Figure 4 - A and B). The green line shows the link between logistics integration and cost; when the level of special treatment benefits is high, the red line shows a moderate level and the blue line refers to low levels of special treatment benefits. As can be seen, the slope of the green line is more than the other two other lines, revealing that the relationship between logistics integration and cost is stronger compared to the other two lines (Figure 4. A). The same pattern can be seen for the link between logistics integration and customer services innovation (Figure 4. B). Therefore, the four hypotheses developed in this study have been supported.

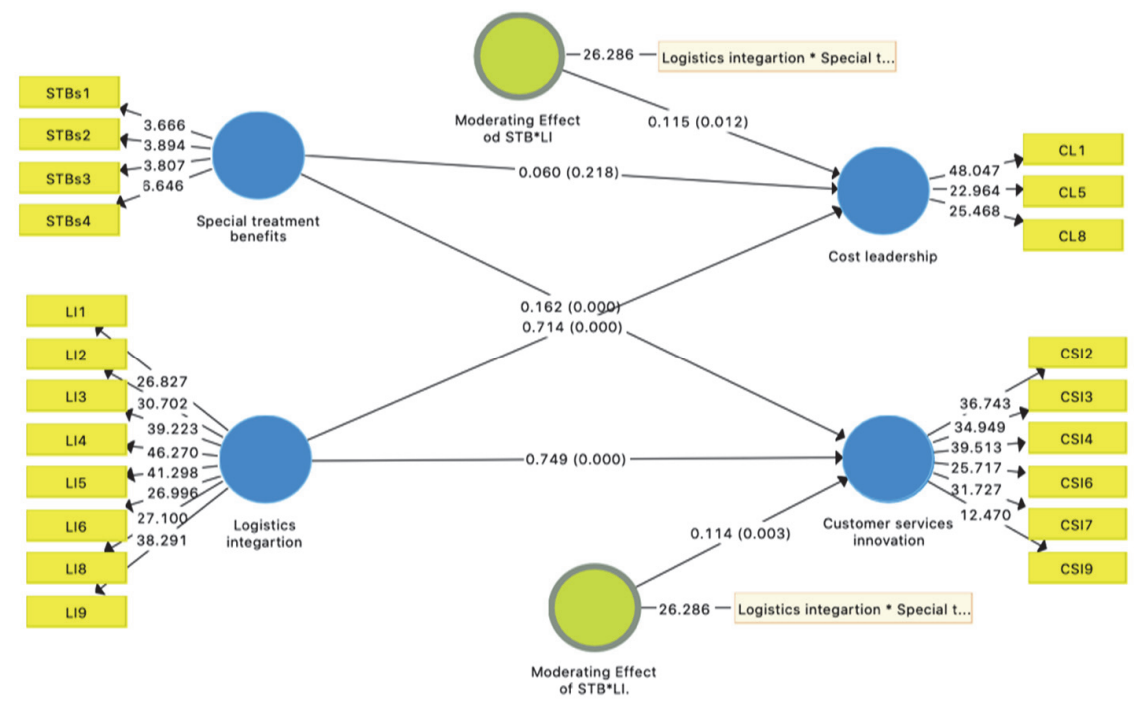

Fig. 3. The Path Model (Bootstrapping) 
Table 6

Testing of Hypotheses using Bootstrapping

\begin{tabular}{|c|c|c|c|c|c|c|}
\hline & Path & $\beta$ & SE & T-value & $P$-values & Remarks \\
\hline H1 & Logistics integration $\rightarrow$ Cost leadership & $0.714 * *$ & 0.031 & 23.280 & $<0.001$ & Supported \\
\hline $\mathrm{H} 2$ & Logistics integration $\rightarrow$ Customer service innovation & $0.749 * *$ & 0.025 & 30.495 & $<0.001$ & Supported \\
\hline $\mathrm{H} 3$ & Logistics integration $\times$ Special treatment benefits $\rightarrow$ Cost leadership & $0.115^{*}$ & 0.046 & 2.512 & 0.012 & Supported \\
\hline $\mathrm{H} 4$ & Logistics integration $\times$ Special treatment benefits $\rightarrow$ Customer services innovation & $0.114 * *$ & 0.038 & 2.982 & 0.003 & Supported \\
\hline
\end{tabular}
e Critical t-values. $2.58^{* *}(\mathrm{p}<0.01), 1.96^{*}(\mathrm{p}<0.05),(2$-tailed $)$

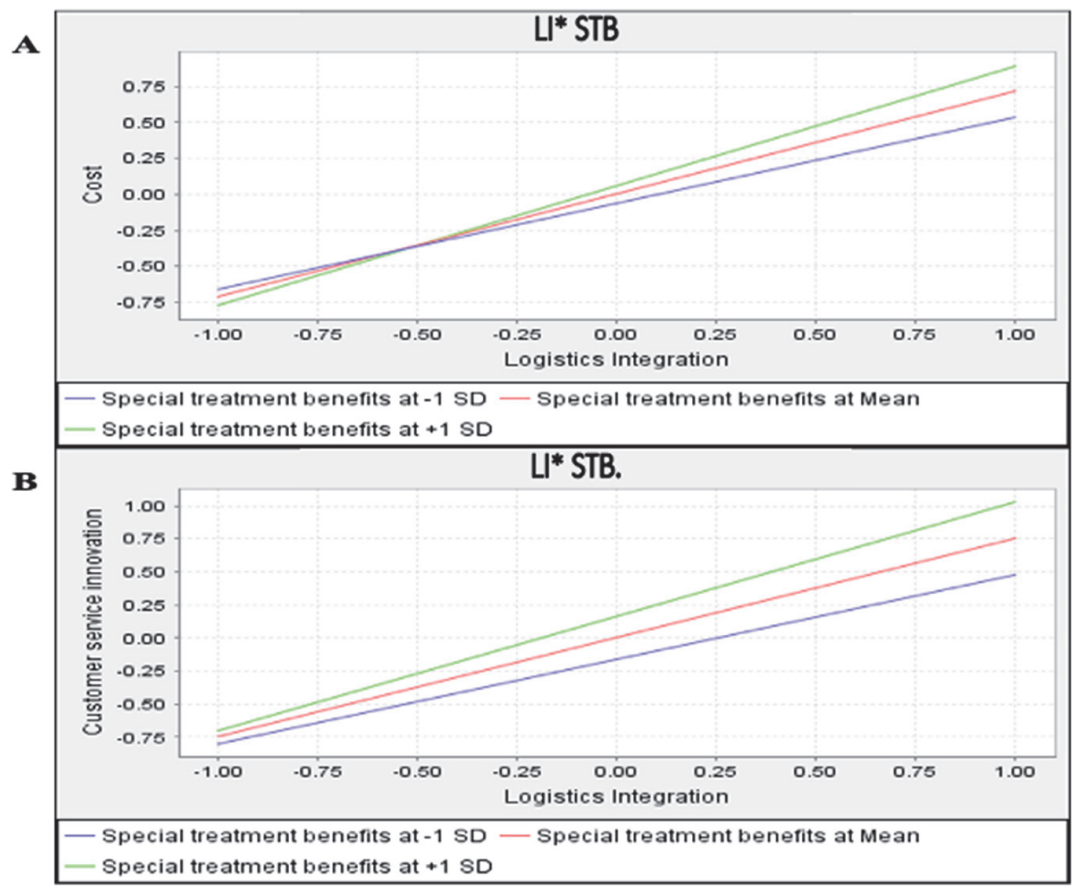

Fig. 4. Slope Analysis for Moderation Effect of Special Treatment Benefits: (A) showing relationship between logistics integration and cost; and (B) showing relationship between logistics integration and customer services innovation.

\section{Discussion and Implications}

The results of this study provide empirical evidence that the four hypotheses are positive and significant. The results confirm that logistics integration between LSPs and their key clients is positively significant, in terms of cost leadership and customer services innovation. The results further confirm that providing clients with special treatment benefits, positively and significantly moderates the relationship between LSP-client logistics integration and LSPs' cost leadership and customer services innovation. However, the significant relationship found between logistics integration and the two performances, is not in tandem with He, Zhang, and He (2019) and Wiengarten et al. (2019), but concur strongly with other logistics and supply chain literature (e.g., Deepen, Goldsby, Knemeyer, \& Wallenburg, 2008; Skjoett-Larsen, 2000; Stank, Goldsby, Vickery, \& Savitskie, 2003), that customer cooperation with LSPs has a direct effect on customer satisfaction by enhancing LSPs' ability to comprehend and meet customer requirements. The results support the finding of Yang and Zhao (2016) that logistics integration practices, in terms of information exchange, , and better problem solving, lead to improving reliability, on-time delivery, flexibility and overall satisfaction. The results reveal that the ability of LSPs to develop joint solutions, lead to faster delivery and on-time information sharing, in turn, fostering cooperative partnership, seamless joint planning and innovation capability. These results are similar to that of Erna et al. (2019), who found LSPs' collaboration with clients leads to incremental, radical and open-innovation and improves the supply chain performance as a whole. The result is also consistent with Wagner and Sutter (2012), who proved that the degree of client integration influences LSPs' ability to innovate and achieve cost reduction as well as customer satisfaction. The results suggest that LSPs can achieve competitive cost and services but the effectiveness of this achievement depends on the LSPs' ability to solve operational problems jointly with their key clients, work as a team to improve the logistics process and make joint decisions, and collectively, achieve shared goals. This is because those integrative practices provide an avenue for generating and communicating critical information, which enable the seizing of possible opportunities of learning and acquiring knowledge and skills, thereby making collaboration more likely to yield performance benefits for all (Wang, Dou, Zhu, \& Zhou, 2015; Yang et al., 2018). The results are in line with Kirono et al. (2019) and Liu et al. (2015), who found integrative mechanisms with extensive information sharing, enhance logistics capabilities, such as knowledge-based capabilities, leading to improvement in service quality, delivery, and flexibility (Liu et al., 2015); as well as transportation cost (Kirono et al., 2019). Establishing an effective integration relationship with clients 
can enable data to be accessed and utilized by LSPs and different parties in the logistics network toward more effective decision-making. For example, sharing production and demand data can facilitate partner integration and collaborative planning. This can minimise inventory buffers by reducing cycle time and costly value-adding operations, leading to accurate tracking and enhancement in responsiveness and flexibility, which in turn, help the overall competitiveness of the LSPs' operational performance.

Logisticians should understand the importance of managing their shared resources and capabilities in partnership to ensure positive performance outcomes. The detection of the logistics integration effect is essential due to the value generated for partners involved (Dyer, Singh, \& Hesterly, 2018). As argued by pervious strategy theorists (Das \& Teng, 2000; Ireland et al., 2002), inter-firm collaboration creates value by providing access to previously inaccessible resources and broadening the application of resources to attain unique configuration so that its value is maximised comparative to other potential combinations (Das \& Teng, 2000; Ireland et al., 2002), that change firms' competitiveness (Bettis \& Hitt, 1995; Das \& Teng, 2000; Lei, Hitt, \& Bettis, 1996). The LSPs should invest to develop logistics integration capability; otherwise, it will not be easy to achieve the desired logistics performance outcomes in today's market place. This is because an accurate pattern of how LSPs and their key clients build unique configuration or combination, becomes less immutable. Hence, logistics firms operating during the global outbreak of the COVID-19 must reflect on the rapid changes in the logistics services context. Accordingly, Malaysian LSPs who take advantage of logistics integration and adapt their business to it, are in a better position to produce appropriate logistics solutions and promote customer services innovation and reduction cost. This implies that logistics managers should be involved in logistics integration with their clients and should provide the necessary resources, such as sophisticated technology and qualified staff to facilitate their collaboration and coordination practices. With an integrative relationship with clients, the LSPs can obtain the needed resources in order to seize possible opportunities of learning and acquiring knowledge and skills, making collaboration more likely to succeed and yield performance benefits in cost and services innovation. Although logistics integration is found to have a strong impact on cost and customer services innovation, further analysis shows that a high level of logistics integration has an interactive association with a high level of special treatment benefits (moderating effect), and in turn, both can maintain logistics performance at a high level. The results are inconsistent with Lee et al. (2015) and Gremler et al. (2019). Gremler et al. (2019) confirmed that special treatment benefits can predict satisfaction, loyalty and the service provider's performance through relationship quality. This might be because most of the previous examinations have either estimated special treatment benefits as a predictor or as a mediator but not as a moderating variable that can influence loyalty components (Soni, 2019). However, the results are aligned with Li et al. (2012), who proved that what drives relational outcomes, commitment, trust, and clients-LSPs long-term strategic relationship, is offering clients special treatment benefits. The results are similar to those of Balci et al. (2019); they found financial benefits have a strong total effect on customers' loyalty and satisfaction. The results imply that LSPs have the ability to develop a mutual understanding of responsibilities, informally work together to improve logistics processes and jointly design customised order processes, but the continuity and stability of these integration practices depend on clients receiving high levels of special treatment benefits. This is because the interaction between them is likely to be the direct source of cost and service advantages. The results concur with Lien et al. (2018), that a high level of those benefits in terms of better interest rates, and discounts, moderate the customers' positive mood and WOM relationship. The results are also aligned with Palaima and Auruškeviciene (2007), who found that achieving service quality and providing customers' special treatment benefits, affect relationship commitment. The results of the moderating effects of special treatment benefits helped in achieving the aim of this study. The detection of moderating effects provides valuable insights into how LSPs can maintain their performance outcomes. The results of this study suggest that a good practice for LSPs in forming an integration relationship with clients is to establish strong economic incentives, in terms of competitive prices, shipping rates, favourable payment terms, attractive discounts and clear description and detailed pricing for all quotations. This is because the LSPs' abilities to offer special treatment benefits to their major clients will help them build a value-based relationship perception, so that clients perceive their relationship as successful. Only through commitment and investment in continuity of collaboration practices with providers can gains be continuously achieved, which is consistent with the conclusions reported by Li (2011). This implies that Malaysian LSPs should understand that escalating global competition, especially during the COVID-19 pandemic, has made clients more price sensitive; thus, offering special treatment benefits is essential because of the need to fulfil the relationship bonds which are mainly based on economic incentives. The significant moderating effects authenticate the concept of value in RM because it is confirmed that the provision of customer value appropriation represented by relational benefits (or special treatment benefits) is fundamental to LSPs' long-term success (Gwinner et al., 1998; Itani, Kassar, \& Loureiro, 2019; Kumar \& Reinartz, 2016). The results are also aligned with strategy theorists' arguments that participation in inter-firm collaboration can either benefit or damage the quest of a firm for competitive advantage when the firm overlooks the parallel distribution of common benefits (Andersén, 2011; Khanna et al., 1998; Lavie, 2006, 2007). This is because the doubt of the partner's opportunistic behaviour would restrict the scope of collaboration and transfer of knowledge (Dyer \& Singh, 1998; Dyer et al., 2018; Lavie, 2006). Therefore, the new findings of this study reflect the importance of clients' special treatment benefits in the study model. LSPs should understand that an attempt to achieve competitive advantage from logistics integration without considering their clients' appropriate benefits, will undermine collaboration practices, thus damaging the quest for competitive advantage. Logistics integration involves closely working together; therefore, LSPs should offer extensive monetary benefits beyond the core service to their major clients to encourage continuity of collaboration practices among them, which in turn, will combine and interact to contribute to the LSPs' competitive cost and service. Malaysian LSPs should understand the need to craft value-based relationship strategies for clients that exhibit an extensive level of patronage in order to build confidence in the 
relationship, thereby maintaining collaborative practices. The fulfilment of relationship benefits will help LSPs to reduce the probability of opportunistic behaviour (Cheng et al., 2013); nurture trust and commitment to ensure that integrators accept each other's motives as positive (Tsanos, 2016); reinforce loyalty (Palaima \& Auruškeviciene, 2007); enhance willingness to share knowledge and information (Cheng et al., 2013; Tsanos, 2016); encourage continuity and stability of long-term collaboration relationship (Hunt \& Morgan, 1995); and create a more difficult to replicate relationship building strategies (Ulaga \& Eggert, 2006b; Zhang \& Du, 2019), thereby bringing about positive performance outcomes (Li, 2011; Tsanos, 2016). Special treatment benefits built in this manner will increase the clients' perception that their relationship with LSPs is a reciprocalbased relationship, which in turn, will build strong clients' trust and commitment, reinforce their loyalty, and allow the sharing of knowledge. Logistics managers should realise that competitive advantage derived from special treatment benefits in the logistics integration context, are more difficult for competitors to imitate because it is mainly founded on value-based relationship building strategies which involve financial engagement. These then become accumulated knowledge and processes which are socially complex and less likely to be imitated by other LSPs, thereby preserving the link between logistics integration and logistics performance.

\section{Conclusion}

Based on the RV and RM, this study examined the moderating effect of special treatment benefits on the relationship between logistics integration and logistics performance i.e., cost leadership and customer services innovation in the context of LSPs and their clients (customer or supplier). Although the results confirm that logistics integration improves LSPs' logistics performance, the interactions between clients' special treatment benefits and logistics integration, are found to be the conditions to maintain positive performance outcomes derived from logistics integration. Unlike other marketing and logistics studies, it is worth emphasising that this study's results contribute to the RV theory by integrating the RM perspective to reflect the moderation effect of clients' special treatment benefits, which has not been dealt with in previous studies. Another contribution of this study is empirically providing evidence on how the clients' special treatment benefits are the conditions needed to sustain firm performance in the presence of logistics integration. Our knowledge of the LSP's competitive performance has now been enriched from the acknowledgment of the significance of logistics integration to the interaction association with special treatment benefits to persist logistics performance in cost leadership and customer services innovation. As far as the positive interaction association between clients' special treatment benefits and logistics integration is concerned, this study provides new empirical evidence for the logistics, supply chain and marketing literature. Exploring the moderation effect of special treatment benefits may help LSPs realise the importance of creating value for clients in their attempt to appropriate value in profits. Such an insight would enable LSPs to maintain value-based relationships by concentrating on activities that would promote clients' tangible benefits. Specifically, it can enable LSPs to introduce more effective marketing policies and communication that emphasise on clients' special treatment benefits, to build financial confidence in the relationship, thereby encouraging continuity and stability of the logistics integration practices in the long-run to achieve targeted outcomes.

\section{Directions for Future Research}

Although the results are significant, it carries important limitations which are pertinent for future research. The results should be cautiously generalised to other industries and regions. The relative weights of special treatment benefits can differ in other industries in light of the competition level, the stage of the relationship and complexity of the services. Additionally, the data were collected at one point of time; it would be interesting to conduct a longitudinal study to address the issues related to time and long-term partnership before, during and after logistics integration. This study regards logistics integration as an unidimensional construct, but given the complex nature of the various dimensions of logistics integration identified in previous studies, it would be interesting to cover the entire domain of logistics integration construct to examine the interaction effect in each domain independently. The data were collected mainly from LSPs' perspective; future studies, in particular, on the dyadic perspectives of the LSPs and clients, are needed to provide more profound insights. Finally, it would be valuable to extend the current study model by including more variables (antecedents as well as moderators of integration) to provide compressive insights to logistics managers on how to manage their integrative relationship more effectively, to maintain a smooth supply of goods and to achieve competitive cost and services, especially in the new era of the COVID-19 pandemic.

\section{Acknowledgment}

The authors gratefully thank Universiti Teknologi Malaysia-Kuala Lumpur, specifically, my supervisors, Prof. Dr. Nik Hasnaa Bt. Nik Mahmood and Assoc. Prof. Dr. Mas Bambang Baroto. Without them and their exceptional support, the current paper would not have been possible.

\section{References}

Alhathal, F. T., Sharma, P., \& Kingshott, R. P. J. (2019). Moderating effects of service separation on customer relationships with service firms: A social-exchange perspective. Journal of Service Theory and Practice, 29(1), 71-92. doi:10.1108/JSTP-09-2017-0149 
Andersén, J. (2011). Strategic resources and firm performance. Management Decision, 49(1), 87-98. Retrieved from http://dx.doi.org.ezproxy.psz.utm.my/10.1108/00251741111094455

Anderson, J. C., \& Narks, J. A. (1995). Capturing the Value of Supplementary Services. Harvard Business Review, 73(1), 7583. Retrieved from http://search.ebscohost.com/login.aspx?direct=true\&db=bth\&AN=9501303539\&site=ehost-live

Arvis, J.-F., Ojala, L., Wiederer, C., Shepherd, B., Raj, A., Dairabayeva, K., \& Kiiski, T. (2018). The Logistics Performance Index and Its Indicators. Retrieved from https://lpi.worldbank.org/report

Ataseven, C., \& Nair, A. (2017). Assessment of supply chain integration and performance relationships: A meta-analytic investigation of the literature. International Journal of Production Economics, 185, 252-265. doi:https://doi.org/10.1016/j.ijpe.2017.01.007

Balci, G., Caliskan, A., \& Yuen, K. F. (2019). Relational bonding strategies, customer satisfaction, and loyalty in the container shipping market. International Journal of Physical Distribution \&amp; Logistics Management, 49(8), 816-838. doi:10.1108/IJPDLM-02-2019-0051

Barney, J. B. (1991). Firm resources and sustained competitive advantage. Journal of management, 17(1), 99-120.

Bendapudi, N., \& Berry, L. L. (1997). Customers' motivations for maintaining relationships with service providers. Journal of Retailing, 73(1), 15-37. doi:http://dx.doi.org/10.1016/S0022-4359(97)90013-0

Berry. (1995). Relationship marketing of services growing interest, emerging perspectives. Journal of the academy of marketing science, 23(4), 236-245.

Bettis, R. A., \& Hitt, M. A. (1995). The new competitive landscape. Strategic management journal, 16, 7-7.

Brah, S. A., \& Lim, H. Y. (2006). The effects of technology and TQM on the performance of logistics companies. International Journal of Physical Distribution \& Logistics Management, 36(3), 192-209. Retrieved from http://dx.doi.org.www.ezplib.ukm.my/10.1108/09600030610661796

Cao, M., Vonderembse, M. A., Zhang, Q., \& Ragu-Nathan, T. (2010). Supply chain collaboration: conceptualisation and instrument development. International Journal of Production Research, 48(22), 6613-6635.

Carvalho, J., \& Chima, F. O. (2014). Applications of structural equation modeling in social sciences research. American International Journal of Contemporary Research, 4(1), 6-11.

Cheng, J., Chen, S., \& Chen, F. (2013). Exploring how inter-organizational relational benefits affect information sharing in supply chains. Information Technology and Management, 14(4), 283-294.

Chin, W. W. (2010). How to write up and report PLS analyses. In Handbook of partial least squares (pp. 655-690): Springer.

Chin, W. W., Marcolin, B. L., \& Newsted, P. R. (2003). A partial least squares latent variable modeling approach for measuring interaction effects: Results from a Monte Carlo simulation study and an electronic-mail emotion/adoption study. Information systems research, 14(2), 189-217.

Cohen, J. (1988). Statistical power analysis for the behavioral sciences (2nd ed.): Lawrence Erlbaum Associates, Publishers.

Collins, K. M., Onwuegbuzie, A. J., \& Jiao, Q. G. (2006). Prevalence of mixed-methods sampling designs in social science research. Evaluation \& Research in Education, 19(2), 83-101.

Das, T. K., \& Teng, B. (2000). A resource-based theory of strategic alliances. Journal of management, 26(1), 31-61.

Deepen, J. M., Goldsby, T. J., Knemeyer, A. M., \& Wallenburg, C. M. (2008). Beyond expectations: an examination of logistics outsourcing goal achievement and goal exceedance. Journal of Business Logistics, 29(2), 75-105. Retrieved from http://search.ebscohost.com/login.aspx?direct=true\&db=bth\&AN=36996462\&site=ehost-live

Ding, J. F., Shyu, W. H., Yeh, C. T., Ting, P. H., Ting, C. E., Lin, C. P., . . Wu, S. S. (2016). Assessing customer value for express service providers: An empirical study from shippers' perspective in Taiwan. Journal of Air Transport Management, 55, 203-212. doi:https://doi.org/10.1016/j.jairtraman.2016.06.004

Dyer, J. H., \& Singh, H. (1998). The Relational View: Cooperative Strategy and Sources of Interorganizational Competitive Advantage. The Academy of Management Review, 23(4), 660-679. doi:10.2307/259056

Dyer, J. H., Singh, H., \& Hesterly, W. S. (2018). The relational view revisited: A dynamic perspective on value creation and value capture. Strategic management journal, 39(12), 3140-3162. doi:10.1002/smj.2785

Ellegaard, C., Medlin, C. J., \& Geersbro, J. (2014). Value appropriation in business exchange-literature review and future research opportunities. Journal of Business \& Industrial Marketing, 29 (3), 185-198.

Erna, E., Surachman, S., Sunaryo, S., \& Djajuli, A. (2019). Integration between radical innovation and incremental innovation to expedite supply chain performance through collaboration and open-innovation: A case study of Indonesian logistic companies. Uncertain Supply Chain Management, 7(2), 191-202.

Feizabadi, J., Gligor, D., \& Motlagh, S. A. (2019). The triple-As supply chain competitive advantage. Benchmarking: An International Journal, 26(7), 2286-2317.

Flynn, B. B., Huo, B., \& Zhao, X. (2010). The impact of supply chain integration on performance: A contingency and configuration approach. Journal of Operations Management, 28(1), 58-71. doi:10.1016/j.jom.2009.06.001

Fornell, C., \& Larcker, D. F. (1981). Evaluating structural equation models with unobservable variables and measurement error. Journal of marketing research, 18(1), 39-50.

Frohlich, M. T., \& Westbrook, R. (2001). Arcs of integration: an international study of supply chain strategies. Journal of Operations Management, 19(2), 185-200. doi:10.1016/S0272-6963(00)00055-3

Gadde, L., \& Hulthén, K. (2009). Improving logistics outsourcing through increasing buyer-provider interaction. Industrial Marketing Management, 38(6), 633-640. doi:10.1016/j.indmarman.2009.05.010

Gefen, D., Straub, D., \& Boudreau, M. (2000). Structural equation modeling and regression: Guidelines for research practice. Communications of the association for information systems, 4(1), 7. 
Gremler, D. D., Van Vaerenbergh, Y., Brüggen, E. C., \& Gwinner, K. P. (2020). Understanding and managing customer relational benefits in services: a meta-analysis. Journal of the Academy of Marketing Science, 48(3), 565-583.

Gronroos, C. (1990). Relationship Approach to Marketing In Service Contexts: The Marketing and Organizational Behavior Interface. Journal of Business Research, 20(3-11).

Gwinner, K., Gremler, D., \& Bitner, M. (1998). Relational benefits in services industries: the customer's perspective. Journal of the Academy of Marketing Science, 26(2), 101-114.

Hair, J. F., Black, W. C., Babin, B. J., \& Anderson, R. E. (2010). Multivariate Data Analysis; a global perspective (Seventh ed.). Upper Saddle River, New Jersey: Prentice Hall

Hair, J. F., Hult, G. T. M., Ringle, C. M., \& Sarstedt, M. (2014). A Primer on Partial Least SquaresStructural Equation Modeling. Thousand Oaks, CA. : Sage.

Hair, J. F., Hult, G. T. M., Ringle, C. M., \& Sarstedt, M. (2016). A primer on partial least squares structural equation modeling (PLS-SEM): Sage publications.

Hair, J. F., Ringle, C. M., \& Sarstedt, M. (2011). PLS-SEM: Indeed a silver bullet. The Journal of Marketing Theory and Practice, 19(2), 139-152.

Hair, J. F., Risher, J. J., Sarstedt, M., \& Ringle, C. M. (2019). When to use and how to report the results of PLS-SEM. European Business Review, 31(1), 2-24. doi:10.1108/EBR-11-2018-0203

Hair, J. F., Sarstedt, M., Ringle, C. M., \& Gudergan, S. P. (2017). Advanced issues in partial least squares structural equation modeling: SAGE.

Hartmann, E. V. I., \& De Grahl, A. (2011). The flexibility of logistics service providers and its impact on customer loyalty: an empirical study. Journal of Supply Chain Management, 47(3), 63-85. doi:10.1111/j.1745-493X.2011.03228.x

Hazen, B. T., \& Byrd, T. A. (2012). Toward creating competitive advantage with logistics information technology. International Journal of Physical Distribution \& Logistics Management.

He, P., Zhang, S., \& He, C. (2019). Impacts of logistics resource sharing on B2C E-commerce companies and customers. Electronic Commerce Research and Applications, 34, 100820. doi:https://doi.org/10.1016/j.elerap.2018.100820

Hennig-Thurau, T., Gwinner, K. P., \& Gremler, D. D. (2002). Understanding Relationship Marketing Outcomes: An Integration of Relational Benefits and Relationship Quality. Journal of Service Research, 4(3), $230-247$. doi:10.1177/1094670502004003006

Henseler, J., Ringle, C. M., \& Sarstedt, M. (2015). A new criterion for assessing discriminant validity in variance-based structural equation modeling. Journal of the academy of marketing science, 43(1), 115-135.

Henseler, J., Ringle, C. M., \& Sinkovics, R. R. (2009). The use of partial least squares path modeling in international marketing. In R. R. Sinkovics \& P. N. Ghauri (Eds.), New challenges to international marketing (Vol. 20, pp. 277-320). Bingley: Emerald Group Publishing Limited.

Hobbs, J. E. (2020). Food supply chains during the COVID-19 pandemic. Canadian Journal of Agricultural Economics/Revue canadienne d'agroeconomie, 68(2), 171-176. doi:https://doi.org/10.1111/cjag.12237

Hofer, A. R., Knemeyer, A. M., \& Murphy, P. R. (2012). The Roles of Procedural and Distributive Justice in Logistics Outsourcing Relationships. Journal of Business Logistics, 33(3), 196-209. doi:10.1111/j.2158-1592.2012.01052.x

Hunt, S. D., \& Morgan, R. M. (1995). The comparative advantage theory of competition. The Journal of Marketing, 1-15.

Ireland, R. D., Hitt, M. A., \& Vaidyanath, D. (2002). Alliance management as a source of competitive advantage. Journal of management, 28(3), 413-446.

Irfan, M., \& Wang, M. (2019). Data-driven capabilities, supply chain integration and competitive performance: Evidence from the food and beverages industry in Pakistan. British Food Journal, 121(11), 2708-2729. doi:10.1108/BFJ-02-20190131

Itani, O. S., Kassar, A. N., \& Loureiro, S. M. C. (2019). Value get, value give: The relationships among perceived value, relationship quality, customer engagement, and value consciousness. International Journal of Hospitality Management, 80, 78-90. doi:https://doi.org/10.1016/j.ijhm.2019.01.014

Jimenez-Jimenez, D., Martínez-Costa, M., \& Rodriguez, C. S. (2019). The mediating role of supply chain collaboration on the relationship between information technology and innovation. Journal of Knowledge Management, 23(3), 548-567. doi:10.1108/JKM-01-2018-0019

Ju, Y., Wang, Y., Cheng, Y., \& Jia, J. (2019). Investigating the impact factors of the logistics service supply chain for sustainable performance: Focused on integrators. Sustainability, 11(2), 538.

Karia, N. (2011). Resource-based logistics (RBL) and logistics performance. (Degree of Doctor of Philosophy). University of Hull,

Karia, N. (2018b). Knowledge resources, technology resources and competitive advantage of logistics service providers. Knowledge Management Research \& Practice, 16(4), 451-463. doi:10.1080/14778238.2018.1521541

Karia, N. (2019). Halal logistics: practices, integration and performance of logistics service providers. Journal of Islamic Marketing, ahead-of-print(ahead-of-print). doi:10.1108/JIMA-08-2018-0132

Karia, N., Asaari, M. H. A. H., \& Wong, C. Y. (2014). Exploring the comprehensive framework of third-party logistics providers competitive advantage: a resource-based view approach. Australian Journal of Basic and Applied Sciences, 8(23), 345-351.

Karia, N., Wong, C. Y., Asaari, M. H. A. H., \& Lai, K. H. (2015). The Effects of Resource Bundling on Third-party Logistics Providers' Performance. International Journal of Engineering Business Management, 7. 
Khanna, T., Gulati, R., \& Nohria, N. (1998). The dynamics of learning alliances: Competition, cooperation, and relative scope. Strategic management journal, 19(3), 193-210.

Kinard, B. R., \& Capella, M. L. (2006). Relationship marketing: the influence of consumer involvement on perceived service benefits. Journal of Services Marketing, 20(6), 359-368. Retrieved from http://dx.doi.org.ezproxy.psz.utm.my/10.1108/08876040610691257

Kirono, I., Armanu, A., Hadiwidjojo, D., \& Solimun, S. (2019). Logistics performance collaboration strategy and information sharing with logistics capability as mediator variable (study in Gafeksi East Java Indonesia). International Journal of Quality \&amp; Reliability Management, 36(8), 1301-1317. doi:10.1108/IJQRM-11-2017-0246

Kumar, P. (2017). Malaysia poised to be logistics leader. Retrieved from https://themalaysianreserve.com/2017/10/06/malaysia-poised-logistics-leader

Kumar, V., \& Reinartz, W. (2016). Creating enduring customer value. Journal of Marketing, 80(6), 36-68.

Lai, F., Chu, Z., Wang, Q., \& Fan, C. (2013). Managing dependence in logistics outsourcing relationships: evidence from China. International Journal of Production Research, 1-18. doi:10.1080/00207543.2012.752591

Lai, F., Zhao, X., \& Wang, Q. (2006). The impact of information technology on the competitive advantage of logistics firms in China. Industrial Management \& Data Systems, 106(9), 1249-1271. Retrieved from http://dx.doi.org.ezproxy.psz.utm.my/10.1108/02635570610712564

Lavie, D. (2006). The Competitive Advantage of Interconnected Firms: An Extension of the Resource-Based View. The Academy of Management Review, 31(3), 638-658. doi:10.2307/20159233

Lavie, D. (2007). Alliance portfolios and firm performance: A study of value creation and appropriation in the US software industry. Strategic management journal, 28(12), 1187-1212.

Lee, Y. K., Kim, S. K., Kim, M. S., Lee, J. H., \& Lim, K. T. (2015). Relational bonding strategies in the franchise industry: the moderating role of duration of the relationship. Journal of Business \&amp; Industrial Marketing, 30(7), 830-841. doi:10.1108/JBIM-10-2013-0237

Lei, D., Hitt, M. A., \& Bettis, R. (1996). Dynamic core competences through meta-learning and strategic context. Journal of management, 22(4), 549-569.

Lewis, A. (2006). The effects of information sharing, organizational capability and relationship characteristics on outsourcing performance in the supply chain: An empirical study. (3226423 Ph.D.). The Ohio State University, United States - Ohio. Retrieved from https://vpn.utm.my/docview/305304599?accountid=41678 ProQuest Dissertations \& Theses Full Text database.

Li, L. (2011). Assessing the relational benefits of logistics services perceived by manufacturers in supply chain. International Journal of Production Economics, 132(1), 58-67. doi:10.1016/j.ijpe.2011.03.006

Li, L., Ford, J. B., Zhai, X., \& Xu, L. (2012). Relational benefits and manufacturer satisfaction: an empirical study of logistics service in supply chain. International Journal of Production Research, 50(19), 5445-5459. doi:10.1080/00207543.2011.636388

Lien, C. H., Wu, J. J., \& Hsu, M. K. (2018). Positive moods and word-of-mouth in the banking industry: A moderated mediation model of perceived value and relational benefits. International Journal of Bank Marketing, 36(4), 764-783. doi:10.1108/IJBM-05-2017-0097

Liu, C. L., Huo, B., Liu, S., \& Zhao, X. (2015). Effect of information sharing and process coordination on logistics outsourcing. Industrial Management \&amp; Data Systems, 115(1), 41-63. doi:10.1108/IMDS-08-2014-0233

Liu, C. L., \& Lee, M. Y. (2018). Integration, supply chain resilience, and service performance in third-party logistics providers. The International Journal of Logistics Management, 29 (1). doi:

DOI: https://doi-org.ezproxy.utm.my/10.1108/IJLM-11-2016-0283

Lyu, G., Chen, L. B., \& Huo, B. (2019a). The impact of logistics platforms and location on logistics resource integration and operational performance. The International Journal of Logistics Management, 30(2), 549-568. doi:10.1108/IJLM-022018-0048

Mello, J. E., Stank, T. P., \& Esper, T. L. (2008). A Model of Logistics Outsourcing Strategy. Transportation Journal, 47(4), 5-25.

Mentzer, J. T., Min, S., \& Bobbitt, L. M. (2004). Toward a unified theory of logistics. International Journal of Physical Distribution \& Logistics Management, 34(8), 606-627. Retrieved from http://dx.doi.org.ezproxy.psz.utm.my/10.1108/09600030410557758

Moliner-Velazquez, B., Fuentes-Blasco, M., \& Gil-Saura, I. (2014). Value antecedents in relationship between tourism companies. Journal of Business \&amp; Industrial Marketing, 29(3), 215-226. doi:10.1108/JBIM-12-2011-0179

Musia, Z. M. (2013). Factors Influencing Competitive Advantage By East African Breweries Ltd Within Beer Manufacturing Sector In Kenya (Doctoral dissertation). University of Nairobi,

Palaima, T., \& Auruškeviciene, V. (2007). Modeling relationship quality in the parcel delivery services market. Baltic Journal of Management, 2(1), 37-54. doi:10.1108/17465260710720237

Parkhe, A. (1993). Strategic alliance structuring: A game theoretic and transaction cost examination of interfirm cooperation. Academy of Management Journal, 36(4), 794-829.

Pateman, H., Cahoon, S., \& Chen, S. L. (2016). The Role and Value of Collaboration in the Logistics Industry: An Empirical Study in Australia. The Asian Journal of Shipping and Logistics, 32(1), 33-40. doi:https://doi.org/10.1016/j.ajs1.2016.03.004

Porter, M. E. (1980). Competitive Strategy: Techniques for Analyzing Industries and Competitors New York The Free Press. 
Prajogo, D., \& Olhager, J. (2012). Supply chain integration and performance: The effects of long-term relationships, information technology and sharing, and logistics integration. International Journal of Production Economics, 135(1), 514-522. doi:10.1016/j.ijpe.2011.09.001

Ray, G., Barney, J. B., \& Muhanna, W. A. (2004). Capabilities, business processes, and competitive advantage: choosing the dependent variable in empirical tests of the resource-based view. Strategic management journal, 25(1), 23-37. doi:10.1002/smj.366

Richey, R. G., Adams, F. G., \& Dalela, V. (2012). Technology and Flexibility: Enablers of Collaboration and Time-Based Logistics Quality. Journal of Business Logistics, 33(1), 34-49. doi:10.1111/j.0000-0000.2011.01036.x

Ringle, C. M., Wende, S., \& Becker, J. (2015). SmartPLS 3. SmartPLS GmbH, Boenningstedt. Journal of Service Science and Management, 10(3).

Sanders, N. R., \& Premus, R. (2005). Modeling the relationship between firm it capability, collaboration, and performance. Journal of Business Logistics, 26(1), 1-23. doi:10.1002/j.2158-1592.2005.tb00192.x

Sarstedt, M., Ringle, C. M., \& Hair, J. F. (2017). Partial least squares structural equation modeling. Handbook of market research, 26, 1-40.

Sharma, B. (2020, 17 July, 2020). Logistics: challenges and opportunities in the post-covid-19 world. ATOS. Retrieved from https://atos.net/en/blog/logistics-challenges-and-opportunities-in-the-post-covid-19-world\#expert

Sinkovics, R. R., \& Roath, A. S. (2004). Strategic orientation, capabilities, and performance in manufacturer - 3PL relationships. Journal of Business Logistics, 25(2), 43-64. Retrieved from http://search.ebscohost.com/login.aspx?direct=true\&db=inh\&AN=8551685\&site=ehost-live

Situation report The World Health Organization (WHO). Retrieved from https:/www.who.int/docs/defaultsource/coronaviruse/transcripts/transcript-coronavirus-press-conference-full07feb2020-final.pdf?sfvrsn=3beba1c0 2

Skjoett-Larsen, T. (2000). Third party logistics - from an interorganizational point of view. International Journal of Physical $\begin{array}{llllll}\text { Distribution \& } \quad \text { Logistics } & \text { Management, } & 30(2), & 112-127 . & \text { Retrieved from }\end{array}$ http://dx.doi.org.ezproxy.psz.utm.my/10.1108/09600030010318838

Soni, P. (2019). Revisiting the role of relationship benefits in online retail. Marketing Intelligence \&amp; Planning, aheadof-print(ahead-of-print). doi:10.1108/MIP-03-2019-0186

Speranza, M. G. (2018). Trends in transportation and logistics. European Journal of Operational Research, $264(3), 830-836$. doi:https://doi.org/10.1016/j.ejor.2016.08.032

Srivastava, P., Srinivasan, M., \& Iyer, K. N. S. (2015). Relational Resource Antecedents and Operational Outcome of Supply Chain Collaboration. Transportation Journal, 54(2), 240-274. doi:10.5325/transportationj.54.2.0240

Stank, T. P., Goldsby, T. J., Vickery, S. K., \& Savitskie, K. (2003). Logistics service performance: estimating its influence on market share. Journal of Business Logistics, 24, 27-55. doi:doi: 10.1002/j.2158-1592.2003.tb00031.x

Tsanos, C. S. (2016). The effects of behavioural supply chain relationship antecedents on integration and performance. Supply Chain Management: An International Journal, 21(6), 678-693. doi:10.1108/SCM-06-2016-0211

Tuan, L. T. (2017). Under entrepreneurial orientation, how does logistics performance activate customer value co-creation behavior? The International Journal of Logistics Management, 28(2), 600-633.

Ulaga, W., \& Eggert, A. (2006b). Value-based differentiation in business relationships: gaining and sustaining key supplier status. Journal of marketing, 70, 119-136.

Wagner, S. M., \& Sutter, R. (2012). A qualitative investigation of innovation between third--party logistics providers and customers. International Journal of Production Economics, $140(2)$, 944-958. doi:http://dx.doi.org/10.1016/j.ijpe.2012.07.018

Wang, G., Dou, W., Zhu, W., \& Zhou, N. (2015). The effects of firm capabilities on external collaboration and performance: The moderating role of market turbulence. Journal of Business Research, 68(9), 1928-1936. doi:https://doi.org/10.1016/i.jbusres.2015.01.002

Wang, X., Persson, G., \& Huemer, L. (2016). Logistics Service Providers and Value Creation Through Collaboration: A Case Study. Long range planning, 49(1), 117-128. doi:https://doi.org/10.1016/j.lrp.2014.09.004

Watson, G. F., Beck, J. T., Henderson, C. M., \& Palmatier, R. W. (2015). Building, measuring, and profiting from customer loyalty. Journal of the academy of marketing science, 43(6), 790-825.

Wiengarten, F., Li, H., Singh, P. J., \& Fynes, B. (2019). Re-evaluating supply chain integration and firm performance: linking operations strategy to supply chain strategy. Supply Chain Management: An International Journal, 24(4), 540-559. doi:10.1108/SCM-05-2018-0189

Yang, J., Xie, H., Liu, H., \& Duan, H. (2018). Leveraging informational and relational capabilities for performance: An empirical investigation. The International Journal of Logistics Management, 29(3), 985-1000. doi:10.1108/IJLM-042017-0087

Yang, Q., \& Zhao, X. (2016). Are logistics outsourcing partners more integrated in a more volatile environment? International Journal of Production Economics, 171, 211-220. doi:https://doi.org/10.1016/j.ijpe.2015.09.036

Yrjölä, M., Rintamäki, T., Saarijärvi, H., Joensuu, J., \& Kulkarni, G. (2019). A customer value perspective to service experiences in restaurants. Journal of Retailing and Consumer Services, 51, 91-101. doi:https://doi.org/10.1016/j.jretconser.2019.05.030

Yuen, K. F., \& Thai, V. V. (2016). The Relationship between Supply Chain Integration and Operational Performances: A Study of Priorities and Synergies. Transportation Journal, 55(1), 31-50. doi:10.5325/transportationj.55.1.0031 
Yuen, K. F., \& Thai, V. V. (2017). Barriers to Supply Chain Integration in the Maritime Logistics. Maritime Economics \& Logistics, 19(3), 551-572. doi:https://doi.org/10.1057/mel.2016.10

Zeithaml, V. A., Berry, L. L., \& Parasuraman, A. (1996). The behavioral consequences of service quality. Journal of marketing, 60(2), 31-46.

Zhang, J., \& Du, M. (2019). Appropriating value from industrial buyer-seller relationships by leveraging network capability. Management Decision, 57(11), 2911-2939. doi:10.1108/MD-03-2017-0183

Zhang, Q., \& Cao, M. (2018). Exploring antecedents of supply chain collaboration: Effects of culture and interorganizational system appropriation. International Journal of Production Economics, 195, 146-157. doi:https://doi.org/10.1016/j.ijpe.2017.10.014

\section{Appendix: Constructs and Measurement Scales of the Study}

Cost leadership (Karia, Asaari, \& Wong, 2014)

$C L \_1$ Compared to our main competitors; our company has low distribution costs;

CL_5 Compared to our main competitors, our company has low equipment or facilities costs;

$C L \_8$ Compared to our main competitors; our company maintains low manpower costs.

Customer service innovation (Karia, Asaari, \& Wong, 2014)

CSI_4 Compared to our main competitors; our customers are more satisfied with our service level;

CSI_ 2 Compared to our main competitors, our company offers a greater percentage of on-time and accurate delivery.

CSI_6 Compared to our main competitors; our company provides quicker responses to customers;

CSI_7 Compared to our main competitors; our company provides additional services;

CSI_3 Compared to our main competitors; our company offers unique solutions;

CSI_9 Compared to our main competitors; our company provides better services.

Logistics integration (Lai, Chu, Wang, \& Fan, 2013)

LI_l helping to improve processes;

$L I 2$ We hold meetings with our major client on a regular basis to solve problems;

$L I$ 3 We informally work together with our major client;

LI_4 We work together as a team with our major client;

LI 5 We conduct joint planning with our major client to resolve operational problems;

LI_6 We have developed a mutual understanding of responsibilities with our major client;

LI_7 We make joint decisions with our major client about ways to improve cost efficiency;

LI_ 8 We collectively achieve goals with our major client.

LI_9 We jointly design customised order processes with our major client.

Special treatment benefits $(\mathrm{Li}, 2011)$

$S T B \_1$ We provide clear description and detailed pricing for all quotations/bidding to our client;

$S T B \_2$ We offer competitive prices and shipping rates to our client;

$S T B \_3$ We provide favourable payment terms to our client;

$S T B \_4$ We offer attractive discounts to our client.

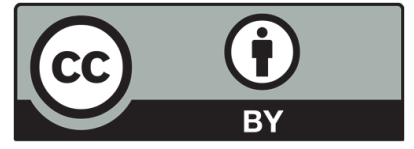

(C) 2021 by the authors; licensee Growing Science, Canada. This is an open access article distributed under the terms and conditions of the Creative Commons Attribution (CC-BY) license (http://creativecommons.org/licenses/by/4.0/). 